\title{
Mechanical circulatory support is effective to treat pulmonary hypertension in heart transplant candidates disqualified due to unacceptable pulmonary vascular resistance
}

\author{
Michał Zakliczyński ${ }^{1}$, Jerzy Pacholewicz ${ }^{1}$, Izabela Copik ${ }^{2}$, Marcin Maruszewski ${ }^{3}$, Tomasz Hrapkowicz ${ }^{2}$, Roman Przybylski ${ }^{4}$, \\ Marian Zembala ${ }^{4}$ \\ ${ }^{1}$ Department of Cardiac, Vascular and Endovascular Surgery and Transplantology, School of Medicine with the Division \\ of Dentistry in Zabrze, Medical University of Silesia in Katowice; Division of Cardiac Surgery, Heart Transplantation and \\ Mechanical Circulatory Support, Silesian Center for Heart Disease, Zabrze, Poland \\ ${ }^{2}$ Division of Cardiac Surgery, Heart Transplantation and Mechanical Circulatory Support, Silesian Center for Heart Disease, \\ Zabrze, Poland \\ ${ }^{3}$ Division of Cardiac Surgery, Heart and Lung Transplantation and Mechanical Circulatory Support, Silesian Center for Heart \\ Disease, Zabrze, Poland; Central Clinical Hospital of the MSWiA in Warsaw, Poland \\ ${ }^{4}$ Department of Cardiac, Vascular and Endovascular Surgery and Transplantology, School of Medicine with the Division \\ of Dentistry in Zabrze, Medical University of Silesia in Katowice; Division of Cardiac Surgery, Heart and Lung Transplantation \\ and Mechanical Circulatory Support, Silesian Center for Heart Disease, Zabrze, Poland
}

Kardiochirurgia i Torakochirurgia Polska 2018; 15 (1): 23-26

\begin{abstract}
Introduction: High pulmonary vascular resistance (PVR) in orthotopic heart transplantation (OHT) candidates is a risk factor of right ventricle failure after the procedure. However, the increase of PVR may be a consequence of the life-threatening deterioration of the left ventricle function. The use of mechanical circulatory support (MCS) seems to be the best solution, but it is reimbursed only in active OHT candidates.

Aim: We performed a retrospective analysis of MCS effectiveness in maintaining PVR at values accepted for OHT.

Material and methods: Starting from the year 2008 we identified 6 patients (all males, $42.8 \pm 17$ years old) with dilated $(n=3)$, ischemic $(n=2)$, and restrictive cardiomyopathy $(n=1)$ in whom MCS - pulsatile left ventricle assist device (LVAD, $n=4$ ), continuous flow $\operatorname{LVAD}(n=1)$, and pulsatile biventricular assist device (BIVAD, $n=1$ ) - was used at a time when PVR was unacceptable for $\mathrm{OHT}$, and the reversibility test with nitroprusside was negative. After an average time of support of $261 \pm 129$ days they were all transplanted.

Results: Right heart catheterization (RHC) results before MCS implantation were as follows: pulmonary artery systolic, diastolic, and mean pressure (PAPs/d/m) $60 \pm 20 / 28 \pm 7 / 40 \pm 11$ $\mathrm{mm} \mathrm{Hg}$, pulmonary capillary wedge pressure (PCWP) $21 \pm 7$ $\mathrm{mm} \mathrm{Hg}$, transpulmonary gradient (TPG) $19 \pm 7 \mathrm{~mm} \mathrm{Hg}$, cardiac output (CO) $3.6 \pm 0.8 \mathrm{l} / \mathrm{min}$, PVR $5.7 \pm 2.1$ Wood units (WU).
\end{abstract}

\section{Streszczenie}

Wstęp: Duże wartości naczyniowego oporu płucnego (PVR) u pacjentów kwalifikowanych do ortotopowego przeszczepienia serca (OHT) niosą ze sobą wysokie ryzyko wystąpienia niewydolności prawokomorowej przeszczepionego serca. Wzrost PVR może jednak wynikać z progresji niewydolności serca do stopnia bezpośrednio zagrażającego życiu pacjenta. Rozwiązaniem, które umożliwia zarówno utrzymanie pacjenta przy życiu, jak i obniżenie PVR do stopnia pozwalającego na wykonanie OHT, jest zastosowanie mechanicznego wspomagania krążenia (MCS). Jest ono jednak refundowane jedynie jako leczenie pomostowe do OHT.

Cel: Retrospektywna ocena materiału własnego, której celem było ustalenie prawdopodobieństwa zakwalifikowania do OHT pacjenta po zastosowaniu MCS.

Materiat i metody: Od 2008 r. zidentyfikowano 6 pacjentów (mężczyźni w wieku 42,8 \pm 17 lat) z kardiomiopatią rozstrzeniową $(n=3)$, uszkodzeniem niedokrwiennym $(n=2)$ i kardiomiopatią restrykcyjną $(n=1)$. Mechaniczne wspomaganie krążenia zastosowano u pacjentów z ciężką niewydolnością serca, u których ze względu na duże wartości PVR bez zadowalających cech odwracalności niemożliwe było wykonanie OHT. Wyniki: W pomiarach ciśnień i oporów płucnych przed zastosowaniem MCS uzyskano następujące wyniki: ciśnienia w tętnicy płucnej - skurczowe, rozkurczowe i średnie (PAs/PAd/

Address for correspondence: Prof. Michał Zakliczyński MD, PhD, Department of Cardiac, Vascular and Endovascular Surgery and Transplantology, School of Medicine with the Division of Dentistry in Zabrze, Medical University of Silesia in Katowice; Division of Cardiac Surgery, Heart Transplantation and Mechanical Circulatory Support, Silesian Center for Heart Disease, 9 M. Curie-Skłodowskiej St, 41-800 Zabrze, Poland, phone: +48 5160731 46, e-mail: zaklimed@onet.pl

Received: 10.10.2017, accepted: 23.12.2017. 
Right heart catheterization results during MCS therapy were as follows: PAPs/d/s $27 \pm 11 / 12 \pm 4 / 17 \pm 6 \mathrm{~mm} \mathrm{Hg}$, PCWP $10 \pm 4 \mathrm{~mm}$ $\mathrm{Hg}$, TPG $7 \pm 4 \mathrm{~mm} \mathrm{Hg}$, CO $5.1 \pm 0.7 \mathrm{l} / \mathrm{min}$, PVR $1.4 \pm 0.6 \mathrm{WU}$. None of the patients experienced right ventricle failure after $\mathrm{OHT}$ with only one early loss due to multiorgan failure.

Conclusions: Mechanical circulatory support is an effective method of pulmonary hypertension treatment for patients disqualified for OHT due to high PVR.

Key words: heart transplant candidacy, mechanical circulatory support.
PAs) $60 \pm 20 / 28 \pm 7 / 40 \pm 11 \mathrm{~mm} \mathrm{Hg}$, ciśnienie zaklinowania (PCW) $21 \pm 7 \mathrm{~mm} \mathrm{Hg}$, gradient przezpłucny (TPG) $19 \pm 7 \mathrm{~mm} \mathrm{Hg}$, minutowy rzut serca (CO) 3,6 $\pm 0,8 \mathrm{l} / \mathrm{min}, \mathrm{PVR} 5,7 \pm 2,1 \mathrm{j}$. Wooda. Próby odwracalności przeprowadzone $z$ nitroprusydkiem sodu $u$ żadnego z pacjentów nie doprowadziły do obniżenia PVR $<2,5$ j. Wooda bez spadku ciśnienia skurczowego $w$ aorcie $<85 \mathrm{~mm} \mathrm{Hg}$. U 5 pacjentów zastosowano wspomaganie lewokomorowe, z czego u 4 zewnętrzną pompą pulsacyjną typu POLVAD, a u 1 pacjenta pompą wszczepialną typu Heart Mate II. U 1 pacjenta zastosowano wspomaganie obukomorowe zewnętrznymi pompami pulsacyjnymi typu POLVAD. Czas wspomagania wyniósł $261 \pm 129$ dni. U wszystkich pacjentów w trakcie stosowania MCS wykazano obniżenie się PVR < 2,5 j. Wooda bez konieczności prowadzenia prób odwracalności: PAs/PAd/PAs 27 $\pm 11 / 12 \pm 4 / 17 \pm 6 \mathrm{~mm} \mathrm{Hg}$, PCW $10 \pm 4 \mathrm{~mm} \mathrm{Hg}$, TPG $7 \pm 4 \mathrm{~mm} \mathrm{Hg}$, CO 5,1 $\pm 0,7 \mathrm{l} / \mathrm{min}$, PVR 1,4 $\pm 0,6$ j. Wooda. U wszystkich pacjentów wykonano $\mathrm{OHT}$, w 1 przypadku nastąpiło wczesne niepowodzenie w przebiegu zespołu niewydolności wielonarządowej.

Wniosek: Zastosowanie MCS jest skuteczną metodą obniżenia PVR u pacjentów wykluczonych wcześniej z OHT z powodu nadciśnienia płucnego.

Stowa kluczowe: kandydatura do przeszczepienia serca, mechaniczne wspomaganie krążenia.

Pulmonary hypertension with high pulmonary vascular resistance (PVR) is a very often diagnosed contraindication for OHT. It is a direct consequence of the left ventricle failure characterized with high diastolic pressure obstructing the collection of blood from the pulmonary vessels. The occurrence of this situation grows with the increasing time of waiting for $\mathrm{OHT}$, and with the progression of the heart failure, which creates the situation where the patient who needs the donor heart the most desperately is at the highest risk of being disqualified for the procedure [3]. Fortunately, it is not a contraindication to use MCS therapy, but how high is the level of the certainty that this treatment is able to compromise PVR in order to perform OHT with acceptable risk of early right ventricle failure?

\section{Aim}

To address this question we performed a retrospective analysis of all patients in whom MCS was introduced at the time when PVR was unacceptable to perform OHT, but thanks to this therapy they were accepted for transplantation and eventually underwent the procedure.

\section{Material and methods}

Starting with the year 2008 we identified all patients in whom MCS was introduced at a time when pulmonary hypertension assessed using a Swan-Ganz catheter during right heart catheterization (RHC) was presumed unacceptable for transplantation: PVR was over 3.0 Wood units (WU), and in the reversibility test performed using sodium nitroprusside or nitroglycerine there was no drop of PVR $<2.5 \mathrm{WU}$, or it was observed along with a decrease of systolic pressure in the aorta below $85 \mathrm{~mm} \mathrm{Hg}$ in the direct

Fig. 1. The results of RHC before and during MCS therapy presented as an average and a standard deviation 
invasive measurement. In patients with multiple $\mathrm{RHC}$ results only the one preceding MCS implantation was taken into consideration. Additionally, we accepted only the patients with RHC performed during MCS therapy in whom we eventually performed OHT.

With these entry criteria we enrolled 6 patients: all males, average age $42.8 \pm 17$ years. Etiology of the heart failure was dilated cardiomyopathy $(n=3)$, ischemic heart disease $(n=2)$, and restrictive cardiomyopathy $(n=1)$. They were treated with the following types of MCS: pulsatile left ventricle assist device (LVAD, $n=4)$, continuous flow LVAD $(n=1)$, and pulsatile biventricular assist device (BIVAD, $n=1$ ).

\section{Results}

The results of RHC before and during MCS therapy are presented as an average and a standard deviation in Figure 1 , and as a range and a median in Figure 2. Only the results of the basic PVR measurement, and not the reversibility test performed before MCS placement, are presented graphically.

Pulmonary vascular resistance did not reach $2.5 \mathrm{WU}$ in any of the RHC performed at the time of MCS; therefore reversible tests were not performed.

All patients successfully underwent OHT after 127-437 days of MCS support (median: 252.0, average: $260.7 \pm 129.4$ days). The only early loss occurred in the $6^{\text {th }}$ week after the procedure and was due to multiorgan failure. In all other patients at least 1-year follow-up is completed. None of the patients suffered from the significant right failure requiring more than standard pharmacological management.

\section{Discussion}

With the series of cases described above we were able to demonstrate that MCS is not only a safety bridge therapy in heart failure patients awaiting a suitable heart donor, but it is an effective way of pulmonary hypertension treatment in order to achieve PVR acceptable for OHT candidates. To make this conclusion unambiguous we decided to include only those patients in whom OHT was eventually performed, considering transplantation as the ultimate clinical verification of the proper qualification for this procedure. However, it should be underlined that we confirmed the expected PVR drop in all MCS patients in whom RHC was performed, while they recovered until MCS cessation, continued therapy awaiting $\mathrm{OHT}$, or unfortunately died on MCS. Similarly to the enrolled individuals, none of these additional patients required a reversibility test during PVR assessment on MCS therapy. Finally, none of the patients matching enrollment criteria was excluded from the study. The natural limitation that was the consequence of this approach was a small number of patients participating in the study.

Left ventricle assist device support is a potent method of left ventricle unloading that is not available for pharmacological means, with the additional ability to mitigate a mitral regurgitation with the hemodynamic effect that is very close to the valve repair procedure $[4,5]$. In fact,

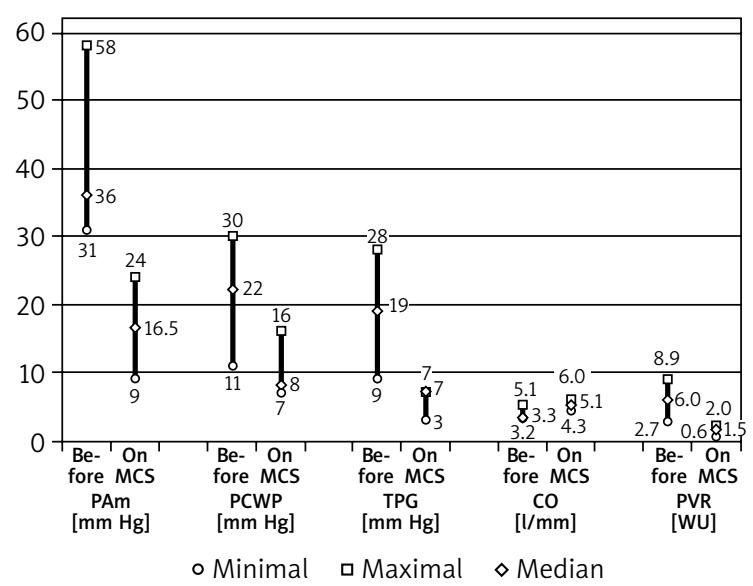

Fig. 2. The results of RHC before and during MCS therapy presented as a range and a median

the group of patients with irreversible pulmonary hypertension falling into the criteria of $\mathrm{OHT}$ should be strongly considered as MCS candidates due to the lack of an effective alternative method of treatment. The legal problem is that the majority of national agencies responsible for MCS reimbursement do not recognize this category of patients, despite being identified in guidelines of both the ESC and ISHLT as individuals bridged to candidacy. While the acceptance to finance MCS treatment is limited worldwide to the bridge to transplantation scenario, it is expected that all MCS candidates will be placed on the official heart transplant waiting list $[2,5]$. With the results of this study we want to raise the argument that it is acceptable to qualify MCS candidates for OHT if high PVR is the only contraindication to the surgery.

Although our experience is still very limited in numbers, our conclusion can be supported not only with the explicit results, but also with the univocal tone of all available publications worldwide considering MCS a successful method of bridging to transplantation even in patients with socalled fixed pulmonary hypertension [6-11]. The majority of these reports documented the result of treatment with continuous flow implantable LVADs, which is becoming the predominant method of MCS use. However, the support from pulsatile pumps is described as equally successful in a number of patients with compromised PVR, even if less impressive in numeric results achieved during RHC [12].

\section{Disclosure}

Authors report no conflict of interest.

\section{References}

1. Lund LH, Edwards LB, Kucheryavaya AY, Benden C, Dipchand Al, Goldfarb S, Levvey BJ, Meiser B, Rossano JW, Yusen RD, Stehlik J. The Registry of the International Society for Heart and Lung Transplantation: Thirty-second Official Adult Heart Transplantation Report--2015; Focus Theme: Early Graft Failure. J Heart Lung Transplant 2015; 34: 1244-1254.

2. McMurray JJ, Adamopoulos S, Anker SD, Auricchio A, Böhm M, Dickstein K, Falk V, Filippatos G, Fonseca C, Gomez-Sanchez MA, Jaarsma T, Køber L, Lip GY, Maggioni AP, Parkhomenko A, Pieske BM, Popescu BA, Rønnevik PK, 
Rutten FH, Schwitter J, Seferovic P, Stepinska J, Trindade PT, Voors AA, Zannad F, Zeiher A. ESC Guidelines for the diagnosis and treatment of acute and chronic heart failure 2012: The Task Force for the Diagnosis and Treatment of Acute and Chronic Heart Failure 2012 of the European Society of Cardiology. Developed in collaboration with the Heart Failure Association (HFA) of the ESC. Eur Heart J 2012; 33: 1787-1847.

3. Zakliczynski M, Zebik T, Maruszewski M, Swierad M, Zembala M. Usefulness of pulmonary hypertension reversibility test with sodium nitroprusside in stratification of early death risk after orthotopic heart transplantation. Transplant Proc 2005; 37: 1346-1348.

4. Zakliczynski M, Maruszewski M, Pyka L, Trybunia D, Nadziakiewicz P, Przybylski R, Zembala M. Effectiveness and safety of treatment with sildenafil for secondary pulmonary hypertension in heart transplant candidates. Transplant Proc 2007; 39: 2856-2858.

5. Feldman D, Pamboukian SV, Teuteberg JJ, Birks E, Lietz K, Moore SA, Morgan JA, Arabia F, Bauman ME, Buchholz HW, Deng M, Dickstein ML, El-Banayosy A, Elliot T, Goldstein DJ, Grady KL, Jones K, Hryniewicz K, John R, Kaan A, Kusne S, Loebe M, Massicotte MP, Moazami N, Mohacsi P, Mooney M, Nelson T, Pagani F, Perry W, Potapov EV, Eduardo Rame J, Russell SD, Sorensen EN, Sun B, Strueber M, Mangi AA, Petty MG, Rogers J. The 2013 International Society for Heart and Lung Transplantation Guidelines for mechanical circulatory support: executive summary. J Heart Lung Transplant 2013; 32: 157-187.

6. Alba AC, Rao V, Ross HJ, Jensen AS, Sander K, Gustafsson F, Delgado DH. Impact of fixed pulmonary hypertension on post-heart transplant outcomes in bridge-to-transplant patients. J Heart Lung Transplant 2010; 29: 1253-1258.
7. Mikus E, Stepanenko A, Krabatsch T, Loforte A, Dandel M, Lehmkuhl HB, Hetzer R, Potapov EV. Reversibility of fixed pulmonary hypertension in left ventricular assist device support recipients. Eur J Cardiothorac Surg 2011; 40: 971-977.

8. Pauwaa S, Bhat G, Tatooles AJ, Aggarwal A, Martin M, Kumar A, Modi H, Pappas PS. How effective are continuous flow left ventricular assist devices in lowering high pulmonary artery pressures in heart transplant candidates? Cardiol J 2012; 19: 153-158.

9. Kutty RS, Parameshwar J, Lewis C, Catarino PA, Sudarshan CD, Jenkins DP, Dunning JJ, Tsui SS. Use of centrifugal left ventricular assist device as a bridge to candidacy in severe heart failure with secondary pulmonary hypertension. Eur J Cardiothorac Surg 2013; 43: 1237-1242.

10. Atluri P, Fairman AS, MacArthur JW, Goldstone AB, Cohen JE, Howard JL, Zalewski CM, Shudo Y, Woo YJ. Continuous flow left ventricular assist device implant significantly improves pulmonary hypertension, right ventricular contractility, and tricuspid valve competence. J Card Surg 2013; 28: 770-775.

11. Gupta S, Woldendorp K, Muthiah K, Robson D, Prichard R, Macdonald PS, Keogh AM, Kotlyar E, Jabbour A, Dhital K, Granger E, Spratt P, Jansz P, Hayward CS. Normalisation of haemodynamics in patients with end-stage heart failure with continuous-flow left ventricular assist device therapy. Heart Lung Circ 2014; 23: 963-969.

12. Ozturk P, Engin AY, Nalbantgil S, Oguz E, Ayik F, Engin C, Yagdi T, Erkul S, Balcioglu O, Ozbaran M. Comparison of continuous-flow and pulsatile-flow blood pumps on reducing pulmonary artery pressure in patients with fixed pulmonary hypertension. Artif Organs 2013; 37: 763-767. 